\title{
Peran Media Massa Dalam Pengembangan Budaya Akademik Mahasiswa Kabupaten Sumbawa
}

\author{
Edy Kurniawansyah ${ }^{1}$, Sumitro ${ }^{2}$ \\ ${ }^{1,2}$ Institut Ilmu Sosial dan Ilmu Budaya Samawa Rea \\ E-mail: almusukyedy@gmail.com, sumitro765@gmail.com
}

\begin{abstract}
Abstrak. Riset ini mendeskripsikan peran media massa dalam mengembangkan budaya akademik mahasiswa. Tujuan penelitian ini adalah untuk mendeskripsikan bentuk budaya akademik mahasiswa di Kabupaten Sumbawa, dan mendeskripsikan peran media massa dalam pengembangan budaya akademik mahasiswa di Kabupaten Sumbawa tersebut. Jenis penelitian yang digunakan adalah deskriptif kualitatif. Tempat penelitian di Kabupaten Sumbawa. Waktu penelitian mulai bulan Januari sampai Mei 2020. Subjek penelitian mahasiswa dari tiga perguruan tinggi di kabupaten Sumbawa. Teknik pengumpulan data menggunakan observasi, wawancara dan dokumentasi. Keabsahan data menggunakan triangulasi sumber. Teknik analisis data dengan pengumpulan data, reduksi data, penyajian data, dan kesimpulan. Berdasarkan hasil penelitian dan pembahasan diatas, selanjutnya dapat ditarik kesimpulan bahwa terdapat beberapa kegiatan mahasiswa yang berpotensi menunjang terbentuknya budaya akademik yaitu; a.) Penggunaan media sosial kegiatan kemahasiswaan, b.) Penggunaan website kajian akademik, c.) Penggunaan media sosial aktifitas perkuliahan, d.) mengakses jurnaljurnal online referensi akademik. Adapun peran Media Massa dalam pengembangan budaya akademik Mahasiswa di Kabupaten Sumbawa meliputi; Sumber informasi intelektual dan Media publikasi. Optimalisasi peran media di lingkungan berpotensi mengembangkan budaya akademik mahasiswa. Sehingga yang penting untuk dilakukan adalah dengan menumbukkan kesadaran pengguna media digital bukannya membatasi akses. Salah satu usaha untuk menumbuhkan kesadaran tersebut adalah dengan mengembangkan budaya akademik tersebut.
\end{abstract}

\section{Kata Kunci: Media Massa, Budaya Akademik, Mahasiswa}

Abstract. This research describes the role of mass media in developing student academic culture. The purpose of this research is to describe the forms of student academic culture in Sumbawa Regency, and describe the role of the mass media in the development of student academic culture in the Sumbawa Regency. The type of research used is descriptive qualitative. Research site in Sumbawa Regency. The study period starts from January to May 2020. The research subjects are students from three tertiary institutions in Sumbawa Regency. Data collection techniques using observation, interviews and documentation. Data validity uses source triangulation. Data analysis techniques with data collection, data reduction, data presentation, and conclusions. Based on the results of the research and discussion above, it can be concluded that there are several student activities that have the potential to support the formation of an academic culture, namely; a.) Use of social media student activities, b.) Use of academic study websites, c.) Use of social media lecture activities, d.) access academic references online journals. The role of Mass Media in the development of Student academic culture in Sumbawa Regency includes; Source of intellectual information and media publications. Optimizing the role of media in the environment has the potential to develop student academic culture. So the important thing to do is to increase awareness of digital media users instead of restricting access. One effort to foster that awareness is to develop the academic culture.

Keywords: Mass Media, Academic Culture, Students

\section{PENDAHULUAN}

Media massa merupakan alat atau sarana komunikasi dan informasi yang dapat melakukan penyebaran informasi secara 
massa dan dapat diakses oleh masyarakat secara massa juga. Perkembangan informasi yang diterima oleh masyarakat pada prinsipnya sebanding dengan kemajuan teknologi. Perkembangan informasi inilah yang menjadikan masyarakat tidak memiliki batasan untuk berinteraksi dan berkomunikasi baik dalam lingkup nasional maupuninternasional.

Fenomena tersebut, saat ini sudah berkembang ke arah modernisasi sehingga melahirkan hubungan yang signifikan antara media massa dan pengembangan budaya akademik mahasiswa. Hubungan tersebut dapat diungkapkan melalui sebuah argumen bahwasannya keberadaan media massa dapat menyebabkan atau mempengaruhi terjadinya perubahan budaya akademik mahasiswa. Media massa dipahami sebagai alat yang digunakan untuk menyampaikan informasi. Kelebihan media massa dapat membantu untuk mempermudah penyebarluasan informasi secara menyeluruh kepada seluruh lapisan masyarakat dan cepat dibandingkan jika disampaikan secara face to face yang kurang efektif dan efisien. Selain itu media massa juga mempunyai peran yang sangat penting bagi kehidupan masyarakat modern dan terlebih untuk pengembangan budaya akademik.

Sadar atau tidak sadar media massa telah menjadi bagian penting dalam kehidupan masyarakat. Adapun peran penting media massa dalam kehidupan masyarakat adalah pertama,media massa dapat memperluas cakrawala pemikiran. Kedua,media massa dapat memusatkan perhatian. Pemusatan perhatian tersebut dapat dilakukan ketika suatu budaya masyarakat tergerus oleh arus globalisasi dan modernisasi, sehingga dalam hal ini media dapat menanyangkan tayangan yang dapat memperkuat adanya keberadaan budaya tersebut. Ketiga,mampu meningkatkan aspirasi masyarakat. Melalui adanya informasi yang ditayangkan secara tidak langsung akan menimbulkan aspirasi atau keinginan dari masyarakat. (Paul dkk,2013). Berdasarkan penjelasan tersebut maka peran penting media massa adalah menyampaikan informasi secara terus menerus sehingga dengan harapan cepat atau lambat akan mempengaruhi pola berfikir masyarakat pada umumnya dan terlebih khusus pada masyarakat kampus dalam pengembangan budaya akademiknya yang berlanjut pada sebuah formasi tindakan ril.

Senada dengan tujuan dan arah pendidikan Tinggi di Indonesia seperti yang tertuang pada Bab II pasal 2 Keputusan Menteri Pendidikan No.232/U/2000 adalah menyiapkan peserta didik untuk menjadi anggota masyarakat yang memiliki kemampuan akademik dalam menerapkan, mengembangkan, dan/atau memperkaya khasanah ilmu pengetahuan, teknologi dan atau kesenian, serta menyebarluaskan dan mengupayakan penggunaannya untuk meningkatkan taraf kehidupan dan memperkaya kebudayaan nasional. Ini berarti kinerja akademik dituntut dilaksanakan secara kompetitif dengan kualitas unggul. Kinerja akademik yang tidak berorientasi pada kualitas unggul, tidak saja akan tertinggal dalam persaingan tetapi juga akan bergantung pada dunia luar yang lebihmaju.

Perubahan lingkungan dan masyarakat baik yang disebabkan oleh faktor internal maupun eksternal, membawa dampak pada perubahan di bidang pendidikan nasional pada umumnya dan Fakultas Ilmu Sosial pada khususnya. Perkembangan masyarakat yang semakin kompleks menuntut Perguruan tinggi memiliki dan mengembangkan budaya akademik yang dapat membentuk mahasiswa agar memiliki jatidiri dan kompetensi dibidangnya. Menurut Tylor, sebagai mana dikutip oleh Brown (1871), budaya adalah" the complex whole which includes knowledge, belief, art, morals, law, custom, and any other capabilities and habits acquired by man as a member of society" (sekumpulan pengetahuan, keyakinan, seni, moral, hukum, adat, kapabilitas, dan kebiasaan yang diperoleh seseorang sebagai anggota sebuah perkumpulan atau komunitas tertentu). Dengan demikian budaya akademik berarti apa yang dipelajari oleh mahasiswa selama periode waktu tertentu dari Universitas, Fakultas atau Jurusannya. Pengembangan budaya akademik ini didasarkan atas dua tantangan yang selalu dihadapi oleh 
pendidikan tinggi dalam penyelenggaraan pendidikannya yaitu tantangan yang bersifat internal daneksternal.

Tantangan faktor internal menunjuk pada adanya perubahan sumber daya manusia hasil didikan Perguruan Tinggi yang sematamata tidak hanya berdasarkan pada persyaratan penguasaan ilmu dan ketrampilan, tetapi juga pada persyaratan sikap dan semangat belajar, pengenalan bidang lapangan pekerjaan dan kepercayaan masyarakat terhadap pendidikannya serta adanya semangat otonomi sesuai dengan UU No.32 tahun 2004. Sedangkan tantangan yang bersifat eksternal menunjuk pada adanya persaingan tenaga kerja yang menglobal, tuntutan pendidikan tinggi yang humanis, internasionalisasi pendidikan yang bersifat lintas negara yang dalam era globalisasi disebut dengan istilah 'etnoscapes'. Demikian juga peran media massa yang tidak kalah pentingnya memberi warna tersendiri dalam pergumulan dunia kampus yang cenderung dimaknai oleh kalangan civitas akademik sebagai tempat untuk beradu fashion, sebagai tempat trendi-trendian, sebagai tempat tebar pesona dan bermain cinta masa muda, dengan kesibukan untuk kian menegaskan gaya hidup baru yang dibentuk oleh modernisasi lewat media massa. Sehingga tidak heran jika banyak mahasiswa yang hanya datang ke kampus, duduk dan diam mendengarkan penyelasan dari dosen kemudian pulang. Mereka lebih nyaman berlama-lama di mall, tempat hiburan, tempat rekreasi, untuk menikamati indahnya dunia masa muda dengan semakin menyuburkan sikap hedonis dan konsumtif dalam jiwa mereka.

Guna mencapai tujuan pendidikan, salah satu fator penting dalam penyelenggaraan pendidikan tinggi harus didukung oleh sistem organisasi pendidikan yang baik, sarana dan prasarana yang memadai (kualiatas SDM dan fasilitas yang dibutuhkan untuk mendukung proses belajar dan mengajar), juga dipengaruhi oleh fator kurikulum yang tepat. Pada hakikatnya pendidikan tidak hanya bertujuan untuk mengembangkan keilmuan, tetapi juga membentuk kepribadian, kemandirian, keterampilan sosial, dan karakter (Zuchdi,
2010). Sehingga pengembangan budaya akademik menjadi titik temu antara upaya pembinaan karakter dengan peningkatan kualitas sebagai hasil dari proses pendidikan tinggi. Karakter merupakan bagian integral dari budaya akademik, mengingat karakter diperlukan dan berpotensi dikembangkan dari setiap aktivitas akademik.

Peran media massa dalam kehidupan dan kegiatan akademik diharapkan selalu berkembang, bergerak maju bersama dinamika perubahan dan pembaharuan sesuai tuntutan zaman. Perubahan dan pembaharuan dalam kehidupan dan kegiatan akademik menuju kondisi yang ideal senantiasa menjadi harapan dan dambaan setiap insan yang mengabdikan dan mengaktualisasikan diri melalui dunia pendidikan tinggi dan penelitian, terutama mereka yang menggenggam idealisme dan gagasan tentang kemajuan. Perubahan dan pembaharuan ini hanya dapat terjadi apabila digerakkan dan didukung oleh pihak-pihak yang saling terkait, memiliki komitmen dan rasa tanggungjawab yang tinggi terhadap perkembangan dan kemajuan budaya akademik.

\section{TINJAUAN PUSTAKA}

\section{Media Masa}

a. Pengertian Media Massa

Menurut Leksikon Komunikasi, media massa adalah "sarana penyampaian pesan yang berhubungan langsung dengan masyarakat luas misalnya radio, televisi, dan surat kabar". Media adalah bentuk jamak dari medium yang berarti tengah atau perantara. Massa berarti berasal dari bahasa inggris yaitu mass yang berarti kelompok ataukumpulan. Dengan demikian, pengerttian media massa adalah perantara atau alat-alat yang digunakan oleh massa dalam hubungannya satu sama lain (Soehadi, 1978).

b. Peran Media Massa

$$
\text { Denis McQuail }
$$

mengemukakan sejumlah peran yang dimainkan media massa selama ini, yakni

- Industri pencipta lapangan kerja, barang, dan jasa serta 


$\begin{aligned} & \text { menghidupkan industri } \\ & \text { utamanya }\end{aligned}$
dalam
periklanan/promosi.

- Sumber kekuatan-alat kontrol, manajemen, dan inovasi masyarakat.

- Lokasi (forum) untuk menampilkan peristiwamasyarakat.

- Wahana pengembangan kebudayaan, tatacara, mode, gaya hidup dannorma.

- Sumber dominan pencipta citra individu, kelompok, danmasyarakat.

c. Fungsi Media

Adapun fungsi media menurut Wright adalah:

- Sebagai pengawasan (Surveilance) terhadap ragam peristiwa yang dijalankan melalui proses peliputan dan pemberitaan dengan berbagai dampaknya yaitu tahu, panik, terancam, gelisah, apatis,dsb.

- Menghubungkan (correlation) memobilisasi massa untuk berpikir dan bersikap atas suatu peristiwa ataumasalah.

- Transmisi kultural (cultural transmission) pewaris budaya, dansosialisasi.

- Sebagai media hiburan(entertaiment)

\section{Pengertian Budaya Akademik}

a. Pengertian Budaya

Budaya adalah suatu cara hidup yang berkembang dan dimiliki bersama oleh sebuah kelompok orang dan diwariskan dari generasi ke generasi. Budaya terbentuk dari banyak unsur yang rumit, termasuk sistem agama dan politik, adat istiadat, bahasa, perkakas, pakaian, bangunan, dan karya seni. Bahasa, sebagaimana juga budaya, merupakan bagian tak terpisahkan dari diri manusia sehingga banyak orang cenderung menganggapnya diwariskan secara genetis. Ketika seseorang berusaha berkomunikasi dengan orang-orang yang berbeda budaya dan menyesuaikan perbedaan-perbedaannya, membuktikan bahwa budaya itu dipelajari.

Budaya adalah suatu pola hidup menyeluruh. budaya bersifat kompleks, abstrak, dan luas. Banyak aspek budaya turut menentukan perilaku komunikatif. Unsur-unsur sosio-budaya ini tersebar dan meliputi banyak kegiatan sosial manusia.

b. Pengertian Akademik

Kata akademik berasal dari bahasa Yunani yakni academos yang berarti sebuah taman umum (plasa) di sebelah barat laut kota Athena. Nama Academos adalah nama seorang pahlawan yang terbunuh pada saat perang legendaris Troya. Pada plasa inilah filosof Socrates berpidato dan membuka arena perdebatan tentang berbagai hal. Tempat ini juga menjadi tempat Plato melakukan dialog dan mengajarkan pikiran-pikiran filosofisnya kepada orang-orang yang datang. Sesudah itu, kata acadomos berubah menjadi akademik, yaitu semacam tempat perguruan. Para pengikut perguruan tersebut disebut academist, sedangkan perguruan semacam itu disebut academia (Fajar, 2002). Berdasarkan hal ini, inti dari pengertian akademik adalah keadaan orang-orang bisa menyampaikan dan menerima gagasan, pemikiran, ilmu pengetahuan, dan sekaligus dapat mengujinya secara jujur, terbuka, dan leluasa.

c. Pengertian Budaya akademik

$$
\text { Budaya akademik (Academic }
$$
culture), Budaya Akademik dapat dipahami sebagai suatu totalitas dari kehidupan dan kegiatan akademik yang dihayati,dimaknai dan diamalkan oleh warga masyarakat akademik, di lembaga pendidikan tinggi dan lembaga penelitian. Budaya akademik sebenarnya adalah budaya universal. Artinya, dimiliki oleh setiap orang yang melibatkan dirinya dalam aktivitas akademik. Membangun budaya akademik bukan perkara yang mudah. Diperlukan upaya sosialisasi terhadap kegiatan akademik, sehingga terjadi kebiasaan di kalangan akademisi untuk melakukan 
norma-norma kegiatan akademik tersebut.

Pemilikan budaya akademik ini seharusnya menjadi idola semua insan akademisi perguruan tinggi, yakni dosen dan mahasiswa (Fajar, 2002). Derajat akademik tertinggi bagi seorang dosen adalah dicapainya kemampuan akademik pada tingkat guru besar (profesor). Sedangkan bagi mahasiswa adalah apabila ia mampu mencapai prestasi akademik yang setinggi-tingginya.

d. Pengembangan Budaya akademik

Budaya akademik sebagai suatu subsistem perguruan tinggi memegang peranan penting dalam upaya membangun dan mengembangkan kebudayaan dan peradaban masyarakat (civilized society) dan bangsa secara keseluruhan. Indikator kualitas PT sekarang dan terlebih lagi pada milenium ketiga ini akan ditentukan oleh kualitas civitas akademika dalam mengembangkan dan membangun budaya akademik ini.

Jika sosialisasi tersebut dilakukan secara kontinu, maka ia akan menjadi sebuah tradisi dan budaya bagi individuindividu dalam masyarakat kampus. Norma-norma akademik merupakan hasil dari proses belajar dan latihan dan bukan merupakan bawaanlahir.

Bagi dosen, untuk mencapai derajat akademik guru besar, ia harus membudayakan dirinya untuk melakukan tindakan akademik pendukung tercapainya derajat guru besar itu. Ia harus melakukan kegiatan pendidikan dan pengajaran dengan segala perangkatnya dengan baik, dengan terus memburu referensi mutakhir. Ia harus melakukan penelitian untuk mendukung karya ilmiah, menulis di jurnal-jurnal ilmiah, mengikuti seminar dalam berbagai tingkat dan forum, dan lain-lain. Ia juga harus melakukan pengabdian pada masyarakat untuk meningkatkan pengetahuan, keterampilan, dan kesejahteraan masyarakat.

Bagi mahasiswa, faktor-faktor yang dapat menghasilkan prestasi akademik itu ialah terprogramnya kegiatan belajar, kiat untuk memburu referensi aktual dan mutakhir, diskusi substansial akademik, dan sebagainya. Dengan melakukan aktivitas seperti itu diharapkan dapat dikembangkan budaya mutu (quality culture) yang secara bertahap dapat menjadi kebiasaan dalam perilaku tenaga akademik dan mahasiswa dalam proses pendidikan di perguruan tinggi.

Oleh karena itu, tanpa melakukan kegiatan-kegiatan akademik, mustahil seorang akademisi akan memperoleh nilai-nilai normatif akademik. Boleh jadi ia mampu berbicara tentang norma dan nilai-nilai akademik tersebut di depan forum namun tanpa proses belajar dan latihan norma-norma itu tidak pernah terwujud dalam praktik kehidupan seharihari. Bahkan sebaliknya, ia tidak segansegan melakukan pelanggaran dalam wilayah tertentu, baik disadari maupun tidak disadari.

\section{METODE PENELITIAN}

\section{Pendekatan dan Jenis Penelitian}

Dalam penelitian ini peneliti menggunakan pendekatan kualitatif dimana dalam penelitian ini lebih menekankan pada makna proses daripada hasil suatu aktivitas. Menurut Bagman dan Taylor mendefinisikan metodologi kualitatif sebagai prosedur penelitian yang menghasilkan data deskripsi berupa kata-kata tertulis atau lisan dari orangorang dan perilaku yang diamati. Secara umum penelitian bertujuan untuk memahami (understanding) dunia makna yang disimbolkan dalam perilaku masyarakat menurut masyarakat itu sendiri.

Penelitian kualitatif adalah salah satu metode untuk mendapatkan kebenaran dan tergolong sebagai penelitian ilmiah yang dibangun atas dasar teori- teori yang berkembang dari penelitian dan terkontrol atas dasar empirik. Jadi dalam penelitian kualitatif ini bukan hanya menyajikan data apa adanya melainkan juga berusaha menginterpretasikan korelasi sebagai faktor yang ada yang berlaku meliputi sudut pandang atau proses yang sedangberkembang. Sedangkan jenis penelitian yang 
dipakai oleh peneliti adalah jenis deskriptif kualitatif yang mempelajari masalah-masalah yang ada serta tata cara kerja yang berlaku. Pada hakekatnya penelitian deskriptif kualitatif adalah suatu metode dalam meneliti status kelompok manusia, suatu objek dengan tujuan membuat deskriptif, gambaran atau lukisan secara sistematis, faktual dan akurat mengenai fakta-fakta atau fenomena yang diselidiki.

\section{Lokasi Penelitian}

Penelitian ini dilaksanakan di kampus IISBUD, UTS dan UNSA yang ada di Kabupaten Sumbawa. Adapun alasan dipilihnya kampus tersebut karena merepresentasi budaya akademik mahasiswa yang ada di kabupaten Sumbawa.

\section{Teknik Pengumpulan Data}

Pada tahap penelitian ini agar diperoleh data yang valid dan bisa dipertanggungjawabkan, maka dapat diperoleh melalui:

\section{a. Wawancara}

Wawancara sebagai upaya mendekatkan informasi dengan cara bertanya langsung kepada informan. Adapun wawancara yang dilakukan adalah wawancara tidak terstruktur, dimana di dalam metode ini memungkinkan pertanyaan berlangsung luwes, arah pertanyaan lebih terbuka, tetap fokus, sehingga diperoleh informasi yang kaya dan pembicaraan tidak kaku.

b. Observasi langsung

Observasi langsung adalah cara pengumpulan data dengan cara melakukan pencatatan secara cermat dan sistematis. Observasi harus dilakukan secara teliti dan sistematis untuk mendapatkan hasil yang bisa diandalkan, dan peneliti harus mempunyai latar belakang atau pengetahuan yang lebih luas tentang fokus penelitian mempunyai dasar teori dan sikapobyektif.

c. Dokumen

Proses ini berupa melihat kembali sumber-sumber data dari dokumen yang ada dan dapat digunakan untuk memperluas data-data yang telah ditemukan. Adapun sumber data dokumen diperoleh dari lapangan berupa buku, arsip, majalah,jurnal atau dokumen yang berhubungan dengan fokuspenelitian.

\section{Teknik Analisis Data}

Tahap menaganalisa data adalah tahap yang paling penting dan menentukan dalam suatu penelitian. Adapun teknik Analisis data dalam penelitian ini adalah :

a. Reduksi data (Data Reduction) melakukan analisis data dengan cara merumuskan, memilih hal-hal pokok, memfokuskan pada hal-hal penting, dan membuat kategori sehingga memberikan gambaran agar yang jelas serta mempermudah peneliti dan menganalisis data, langkah-langkah yang dilakukan adalah; (1) informasi wawancara yang diperoleh dari sejumlah informan tentang proses pergeseran makna, faktor yang mempengaruhi dan dampak dari pergeseran makna pernikahan usia muda tersebut dicatat dan dituangkan dalam bentuk tabulasi data, (2) data yang telah dicatat dan ditabulasi diseleksi sehingga yang diambil hanya yang dianggap paling representatif untuk disajikan sebagaidata.

b. Penyajian data (Display Data) mengorganisasikan data, membuat kedalam pola, membuat uraian singkat bagan, hubungan antara kategori, langkah- langkah yang dilakukan adalah; (1). data yang telah diseleksi, internalisasikan dan direlevansikan dengan data etik, (2). informasi yang diperoleh dari wawancara di interprestasikan untuk memberikan gambaran mengenai proses pergeseran makna pernikahan usia muda, faktor penyebab pergeseran makna pernikahan usia muda dan dampak pergeseran makna pernikahan usia muda.

c. Conclusion Drawing/Verivication. Penarikan kesimpulan setelah mengajikan data peneliti akan menarik sebuah kesimpulan untuk menjawab rumusan masalah dan memberikan saran-saran berdasarkan hasil penelitian dan kesimpulam yang 
diambil langkah-langkah yang dilakukan adalah: (1). Mendeskripsiskan fokus masalah yang telah di interperetasi dan dilakukan penarikan kesimpulan,

Kesimpulan sementara direlevansikan dengan hasil observasi lapangan, sehingga memperoleh pemahaman masalah yang sesuai dengan kajian teoritis. (3). Melakukan penyimpulan akhir dan mendeskripsikan sebagai hasilpenelitian.

d. Model Analisis Interaksi. Di mana komponen reduksi data dan sajian data dilakukan bersamaan dengan proses pengumpulan data. Setelah data terkumpul maka ketiga komponen analisi data (reduksi data, sajian data, penarikan kesimpulan,berinteraksi.

\section{Teknik Keabsahan Data}

Untuk memperoleh tingkat keabsahan data, teknik yang digunakan anataralain:

a. Ketekunan pengamatan, yakni serangkaian kegiatan yang dibuat secara terstruktur dan dilakukan secara serius dan berkesinambungan terhadap segala realitas yang ada di lokasi penelitian dan untuk menemukan ciriciri dan unsur-unsur di dalam situasi yang sangat relevan dengan persoalan atau peristiwa yang sedang dicari kemudian difokuskan secara terperinci dengan melakukan ketekunan pengamatanmendalam.

b. Triangulasi data, yakni teknik pemeriksaan keabsahan data yang memanfaatkan sesuatu yang lain diluar data yang terkumpul untuk keperluan pengecekan atau sebagai pembanding terhadap data-data tersebut.

c. Diskusi, yakni diskusi yang dilakukan dengan rekan yang mampu memberikan masukan atau sanggahan sehingga memberikan kemantapan terhadap hasilpenelitian.

HASIL DAN PEMBAHASAN

1. Bentuk Budaya Akademik Mahasiswa Terkait Media Massa

Menurut Koentjaraningrat (1979:

186-187) ada tiga wujud kebudayaan,
Pertama wujud kebudayaan sebagai ide, gagasan, nilai, atau norma. Kedua wujud kebudayaan sebagai aktifitas atau pola tindakan manusia dalam masyarakat. Ketiga wujud kebudayaan sebagai benda-benda hasil karya manusia. Di lingkungan kampus yang sudah kental akan budaya akademik menjadi hal yang sukar untuk memilah mana hal yang sudah membudaya dengan mana yang masih dalam bentuk yang kebiasaan. Butuh pengamatan yang cukup cermat untuk menilai apakah ide, gagasan dan pola perilaku sudah mengkristal dalam bentuk budaya atau hanya sekedar tradisi atau kebiasaan ilmiah semata. Dari temuan tim peneliti ada beberapa budaya akademik mahasiswa di Kabupaten Sumbawa yang terbentuk dari media massa.

a. Penggunaan media sosial untuk melakukan sosialisasi kegiatan kemahasiswaan

b. Penggunaan website untuk merilis berbagai kajian akademik yang dilakukan dalam kelompok belajar, baik di Unit kegiatan Mahasiswa, maupun di Himpunan jurusan maupun program studi.

c. Penggunaan media sosial untuk proses belajar (aktifitas perkuliahan)

d. Penggunaan media sosial untuk mengakses jurnal-jurnal online untuk kepentingan referensi perkuliahan

2. Peran Media Massa dalam Pengembangan Budaya Akademik

Peran Media Massa dalam pengembangan budaya akademik Mahasiswa di Kabupaten Sumbawa sesaui dengan hasil penelitian yang telah dilakukan di berbagai perguruan tinngi yaitu IISBUD, UTS dan UNSA menunjukkan bahwa media massa baik itu media televisi, media internet dan media surat kabar cetak lainya telah dapat dimanfaatkan dengan baik oleh mahasiswa di berbagai perguruan tinggi kabupaten Sumbawa sebagai media sumber informasi. Hal ini nampak dari hasil observasi dan wawancara yang diperoleh selama penelitian ini dilaksanakan di IISBUD, UTS dan UNSA sebagai lokasi penelitian.

Media massa meliputi media cetak, media elektronik dan media online. Media cetak terbagi menjadi beberapa macam 
diantaranya seperti koran, majalah, buku, dan sebagainya, begitupula dengan media elektronik terbagi menjadi dua macam, diantaranya radio dan televisi, sedangkan media online meliputi media internet seperti website, dan lainnya (Yunus, 2010:27).

Secara umum media massa berfungsi sebagai penghubung suatu informasi, dari sumber informasi ke konsumen informasi atau umumnya disebut pengguna informasi. Di kalangan mahasiswa selaku bagian dari civitas akademik kebutuhan akan media masa menjadi penting, dari media masa cetak, elektronik, dan online hingga sosial media. Sosial media terkadang mengandung unsurunsur media masa, karena ada beberapa pengguna media sosial yang menggunakan akunnya untuk memuat berita, opini, artikel, hingga merilis jurnal ilmiah, seperti yang dilakukan oleh banyak institusi pendidikan di Indonesia.

Peran Media Massa dalam pengembangan budaya akademik Mahasiswa di Kabupaten Sumbawa meliputi;

a. Sumber informasi intelektual

Keterbatasan kepustakaan di daerah (dalam hal ini di Sumbawa) membuat media massa berperan penting dalam menyumbang informasi untuk keperluan pengkajian ilmiah. Buku-buku serta jurnal ilmiah online menjadi pilihan paling memungkinkan untuk mengatasi kurangnya buku pelajaran, selain beberapa media massa cetak yang juga menjadi koleksi kepustakaan. Bahkan di beberapa kampus memilih membuat perpustakaan online dari tingkat universitas, fakultas hingga program studi untuk mengatasi masalah referensi ilmiah.

b. Media publikasi

Selain berperan sebagai sumber informasi dan pemelihara budaya akademik, media massa berperan juga sebagai media publikasi. Publikasi yang dilakukan media massa tersebut antara lain; rilis kajian terkait potensi daerah di Sumbawa yang dilakukan oleh mahasiswa, baik dilakukan saat KKN. Rilis kajian diskusi ilmiah yang dilakukan himpunan mahasiswa jurusan.
Rilis kajian diskusi ilmiah yang dilakukan oleh Unit Kegiatan Mahasiswa (UKM). Hingga Rilis kajian ilmiah mahasiswa pada organisasi eksternal kampus.

Optimalisasi peran media di lingkungan berpotensi mengembangkan budaya akademik mahasiswa. Sehingga yang penting untuk dilakukan adalah dengan menumbukkan kesadaran pengguna media digital bukannya membatasi akses. Salah satu usaha untuk menumbuhkan kesadaran tersebut adalah dengan mengembangkan budaya akademik tersebut.

\section{KESIMPULAN}

Berdasarkan hasil penelitian dan pembahasan diatas, selanjutnya dapat ditarik kesimpulan bahwa terdapat beberapa kegiatan mahasiswa yang berpotensi menunjang terbentuknya budaya akademik yaitu;

a. Penggunaan media sosial untuk melakukan sosialisasi kegiatan kemahasiswaan

b. Penggunaan website untuk merilis berbagai kajian akademik yang dilakukan dalam kelompok belajar, baik di Unit kegiatan Mahasiswa, maupun di Himpunan jurusan maupun program studi.

c. Penggunaan media sosial untuk proses belajar (aktifitas perkuliahan)

d. Penggunaan media sosial untuk mengakses jurnal-jurnal online untuk kepentingan referensi perkuliahan

Adapun peran Media Massa dalam pengembangan budaya akademik Mahasiswa di Kabupaten Sumbawa meliputi; Sumber informasi intelektual dan Media publikasi.

Optimalisasi peran media di lingkungan berpotensi mengembangkan budaya akademik mahasiswa. Sehingga yang penting untuk dilakukan adalah dengan menumbukkan kesadaran pengguna media digital bukannya membatasi akses. Salah satu usaha untuk menumbuhkan kesadaran tersebut adalah dengan mengembangkan budaya akademik tersebut.

\section{UCAPAN TERIMA KASIH}

Dengan terlaksananya penelitian ini tidak lupa kami selaku tim peneliti mengucapkan terima kasih kepada 
Kementerian Pendidikan dan Kebudayaan (Kemendikbud) Lembaga Layanan Pendidikan Tinggi Wilayah VIII (Bali Nusa Tenggara) (LLDIKTI-VIII) atas pemberian dana penelitian, sehingga penelitian ini bisa terlaksana sesuai dengan waktu yang ditetapkan.

\section{DAFTAR PUSTAKA}

Baudrillard P, Jean.2004. Masyarakat Konsumsi. Yogyakarta: Kreasi Wacana

Bourdieu, Pierre. 2012. Arena Produksi Kultural: Sebuah Kajian Sosiologi Budaya. TerjemahanSantosa, Yudi. Bantul: Kreasi Wacana

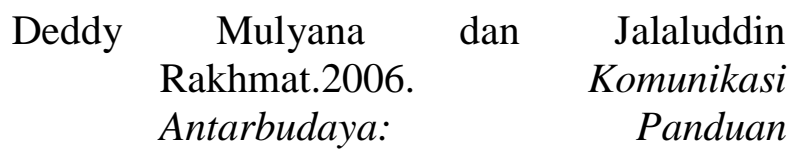
Berkomunikasi dengan Orang-Orang Berbeda Budaya. Bandung: RemajaRosdakarya.

Denis McQuail. 1987. Mass Communication Theori (teori Komunikasi Massa), Erlangga.

Fajar. 2009. Mahasiswa dan Budaya Akademik. Bandung, Rineka.

http://maknaartikel.blogspot.com/2017/01/bu daya-akademik/survei.html http://blogkita.info/budayaakademik-2/

Jurnal Ilmiah Orasi Bisnis-ISSN: 2085-1375 Edisi Ke-VI.

Karnanta, Kukuh Yudha. 2013. Paradigma Teori Arena Produksi Kultural Sastra: Kajian Terhadap Pemikiran Pierre Bourdieu. Jurnal Poetika Vol. 1 No. 1

Keputusan Menteri Pendidikan Nasional Republik Indonesia No. 045/U/2002 tentang Kurikulum Inti Pendidikan Tinggi;

Keputusan Menteri Pendidikan Nasional Republik Indonesia No. 232/U/2000 tentang Pedoman Penyusunan Kurikulum Pendidikan Tinggi dan Penilaian Belajar Mahasiswa

Koentjaraningrat. 1987. Sejarah Teori Antropologi I. Jakarta: UI Press

Novianasari, D \& Samsuri. 2016. Peran Media Massa dalam Meningkatkan Partisipasi PolitikPara Aktivis HMP
PKn di Yogyakarta, SOSIA- Jurnal Ilmu-ilmu Sosial Vol. 13, No. 2, Hal: 13-29. ISSN1829-5797

Paul, Virginia. Singh, Priyanka \& John, Sunit B. @013. Roleof Mass Media In Social Awreness.

Rini. 2011. Peran Media Masaa dalam Mendorong Perubahan Sosial Masyarakat,

Setiawan, Rudy.2013. Kekuatan New Media dalam Membentuk Budaya Populer di Indonesia, e- Journal Ilmu komunikasi, Vol: 1(2), hal: 355-374 ISSN 0000-000.

Syobah, Nurul. 2012. Peran Media Massa Dalam Komunikasi Politik, Jurnal Komunikasi danSosial Keagamaan. Vol: XV, No. 1, Juni 2012

Yunus, Syarifuddin, Jurnalistik Terapan, Bogor: Ghalia Indonesia, 2010 